\title{
Pregnancy outcomes in anti-NMDA receptor encephalitis
}

\section{Case series}

Bastien Joubert, MD, Anna García-Serra, MSc, Jesús Planagumà, PhD, Eugenia Martínez-Hernandez, MD, PhD, Andrea Kraft, MD, Frederick Palm, MD, Takahiro lizuka, MD, PhD, Jérôme Honnorat, MD, PhD, Frank Leypoldt, MD, PhD, Francesc Graus, MD, PhD, and Josep Dalmau, MD, PhD

Neurol Neuroimmunol Neuroinflamm 2020;7:e668. doi:10.1212/NXI.0000000000000668

\section{Abstract}

\section{Objective}

To report the effects of anti-NMDA receptor (NMDAR) encephalitis in pregnant patients and their babies.

\section{Methods}

We studied a retrospective cohort of patients who developed anti-NMDAR encephalitis during pregnancy or became pregnant while recovering from the encephalitis. In addition, we reviewed the English literature between 2010 and 2019 related to this topic.

\section{Results}

We studied 11 patients; 6 developed anti-NMDAR encephalitis during pregnancy, and 5 became pregnant while recovering. There were no obstetrical complications, but 6 (55\%) babies were premature. Ten newborns were healthy, and 1 (9\%) developed transient respiratory distress. Nine infants had assessable follow-up (median 18 months; range, 7-96 months), and all showed normal development. We identified 21 cases in the English literature. Obstetrical complications occurred in 7 (33\%) pregnancies. Two patients died of septic shock ( 1 baby successfully delivered), another 2 had miscarriages, and in 2 , the pregnancy was terminated. Sixteen babies (76\%) were delivered, 9 (56\%) premature. At birth, 13/16 (81\%) newborns were healthy, 2/16 (13\%) had transient neurologic or respiratory symptoms, and 1 (6\%) died of brain edema. Follow-up (median 12 months; range, 6-36 months) was reported for 8 children: 7 (88\%) showed normal development and behavior, and 1 (13\%) cortical dysplasia. Immunotherapy was used during pregnancy in 7 (64\%) of our patients and 18 (86\%) of the reported cases, including rituximab in 4 cases, without adverse effects.

\section{Conclusions}

Patients who develop anti-NMDAR encephalitis during pregnancy or become pregnant during recovery often have obstetrical complications, but most of the newborns are healthy and appear to have normal development.

\author{
Correspondence \\ Dr. Dalmau \\ jdalmau@clinic.cat
}




\section{Glossary}

IVIg = IV immunoglobulin; $\mathbf{m R S}=$ modified Rankin Scale; NMDAR $=$ NMDA receptor

Anti-NMDA receptor (NMDAR) encephalitis is a severe but treatable autoimmune neurologic disease that often results in psychotic symptoms, seizures, dyskinesias, decreased level of consciousness, dysautonomia, or central hypoventilation. ${ }^{1}$ About $60 \%$ of patients are young women, and some develop the disease during pregnancy. ${ }^{1,2}$ Several reports have suggested that dysautonomia, seizures, or central hypoventilation play important roles in the potential complications that pregnant patients may develop. ${ }^{3-7}$ Other studies proposed that transplacental transfer of NMDAR antibodies can result in acute encephalopathy or death of the newborn or eventually result in autistic-spectrum disorders. ${ }^{3,8-10}$ In a study based in an experimental animal model of transplacental transfer of a human monoclonal NMDAR antibody, Jurek et al. ${ }^{11}$ suggested that antibodies of asymptomatic seropositive pregnant women (without evidence of anti-NMDAR encephalitis) caused developmental and cognitive deficits in the offspring. However, the authors did not provide any experimental evidence that the antibodies from asymptomatic mothers of children with cognitive or neurodevelopmental deficits were pathogenic. The best human model to examine the postulate of these authors is pregnant patients with anti-NMDAR encephalitis who all have clear evidence of pathogenic NMDAR antibodies. In fact, the experience and number of reports on pregnant patients with this disease are limited, and the effects of the immune response on patients and offspring are largely unknown. Here, we report 11 new patients and review 21 previously reported cases, describing the effects of the disease on the mothers and babies and the treatments used and outcome.

\section{Methods}

\section{Data collection}

Patients whose serum or CSF were examined for NMDAR antibodies in 3 referral centers (Barcelona, Spain; Lyon, France; and Kiel/Lübeck, Germany) and who were pregnant when they developed anti-NMDAR encephalitis or became pregnant while recovering from the disease were included in the study. Clinical information was retrospectively provided by the treating physicians, patients, and families using a structured questionnaire. We focused on the age and neurologic symptoms of the mothers, presence of an underlying tumor, immunotherapies used during pregnancy, duration of the pregnancy, and type of delivery. Mothers' neurologic outcomes were assessed using the modified Rankin Scale (mRS). ${ }^{12}$ The short-term outcomes of the infants were obtained from records of obstetricians or midwives and the APGAR score 5 minutes after delivery. We reviewed whether the babies were later found to have developmental problems or alterations of behavior and social interaction.

\section{Literature search}

Previously reported cases were identified through MEDLINE search using the following keywords: "NMDAR," "N-methylD-aspartate," "antibodies," "autoimmune encephalitis," and "pregnancy," published between January 1, 2010, and August $15,2019$.

\section{Standard protocol approvals, registrations, and patient consents}

We obtained written informed consent from all patients. The study was approved by the local institutional review boards of Hospices Civils de Lyon (CPP SUD-EST II, US registration number 11263) and Hospital Clínic de Barcelona (registration number $\mathrm{HCB} / 2018 / 0192$ ). All data are available on request at Neuroimmunology Program, IDIBAPS Institute, Barcelona (Spain).

\section{Data availability}

Any data not published within the article are available and will be shared anonymously by request from any qualified investigator.

\section{Results}

\section{Patients of the current series}

We retrospectively assessed the information of 11 cases, including 6 patients $(55 \%)$ who developed anti-NMDAR encephalitis during pregnancy ( 3 in the 1st trimester, 2 in the 2nd trimester, and 1 in the 3rd trimester), and 5 (45\%) who became pregnant during recovery (median time from onset of recovery: 5 months [range, 1-42 months]; median mRS score at the onset of pregnancy: 1 [range, 1-2]). The main clinical features are shown in table 1 (further individual information in Supplemental Material, links.lww.com/NXI/A185). Median age was 23 years (range, 19-37 years), and all patients had combinations of symptoms typical for anti-NMDAR encephalitis, 7 of them (64\%) requiring intensive care. An ovarian teratoma was found and removed in $4(36 \%)$ patients. All patients survived, and at the last visit (median follow-up 28 months; range, 6-144 months), 8/11 (73\%) had minor neurologic disability ( $\mathrm{mRS}$ score $\leq 2$ ). None of the 11 patients had obstetric complications, and all pregnancies were continued until delivery (table 2 ). A caesarean section was performed in $4(36 \%)$ patients because of the severity of the neurologic disease, but there was no case of fetal distress. The postpartum period was uneventful in all cases.

\section{Infants of the current series}

In total, 11 children were born ( 5 females and 6 males), 6 (55\%) preterm (table 3). Ten newborns (90\%) were reported healthy after delivery, and the 5-minute APGAR score was 
Table 1 Clinical features of the patients

\begin{tabular}{|c|c|c|}
\hline & Present series & Literature \\
\hline No. of cases & 11 & 21 \\
\hline Median age (range) & $23(19-37)$ & $25(18-36)$ \\
\hline $\begin{array}{l}\text { NMDAR encephalitis during } \\
\text { pregnancy, } n(\%)\end{array}$ & $6(55)$ & $21(100)$ \\
\hline $\begin{array}{l}\text { Pregnancy onset during recovery } \\
\text { phase, } n(\%)\end{array}$ & $5(45)$ & $0(0)$ \\
\hline Teratoma, n (\%) & $4(36)$ & $10(48)$ \\
\hline \multicolumn{3}{|l|}{ Clinical presentation } \\
\hline First episode, $n(\%)$ & $11(100)$ & $20(95)$ \\
\hline Relapse, n (\%) & $0(0)$ & $1(5)$ \\
\hline \multicolumn{3}{|l|}{ Symptoms, n (\%) } \\
\hline Psychotic symptoms & $11(100)$ & $17(81)$ \\
\hline Anterograde amnesia & $7(64)$ & $9(43)$ \\
\hline Seizures & $6(55)$ & $13(62)$ \\
\hline Dyskinesia & $7(64)$ & $14(67)$ \\
\hline Disintegration of speech & $7(64)$ & $3(14)$ \\
\hline Impairment of consciousness & $7(64)$ & $17(81)$ \\
\hline Central hypoventilation & $3(27)$ & $9(43)$ \\
\hline Autonomic symptoms & $5(45)$ & $9(43)$ \\
\hline Insomnia & $2(18)$ & $3(14)$ \\
\hline Combination of $\geq 3$ symptoms, $n$ (\%) & $11(100)$ & $18(86)$ \\
\hline $\begin{array}{l}\text { Psychotic and cognitive } \\
\text { symptoms only, } \mathrm{n}(\%)\end{array}$ & $0(0)$ & $2(10)$ \\
\hline Seizures only, n (\%) & $0(0)$ & $1(5)$ \\
\hline Admission in ICU, $n(\%)$ & $7(64)$ & $18(86)$ \\
\hline \multicolumn{3}{|l|}{$\begin{array}{l}\text { Neurologic symptoms at the } \\
\text { onset of pregnancy }\end{array}$} \\
\hline None, n (\%) & $6(55)$ & $21(100)$ \\
\hline Anterograde amnesia, n (\%) & $2(18)$ & $0(0)$ \\
\hline Depressed mood/anxiety, n (\%) & $2(18)$ & $0(0)$ \\
\hline Behavioral disturbances, n (\%) & $2(18)$ & $0(0)$ \\
\hline Reduced attention span, n (\%) & $1(9)$ & $0(0)$ \\
\hline Reduced speech fluency, n (\%) & $1(9)$ & $0(0)$ \\
\hline \multicolumn{3}{|l|}{ Immunotherapy during pregnancy } \\
\hline Steroids, n (\%) & $4(36)$ & $17(81)$ \\
\hline IVlg, n (\%) & $4(36)$ & $11(52)$ \\
\hline Plasma exchange, n (\%) & $1(9)$ & $9(43)$ \\
\hline Rituximab, n (\%) & $1(9)$ & $3(14)$ \\
\hline Cyclophosphamide, n (\%) & $0(0)$ & $1(5)$ \\
\hline None, n (\%) & $4(36)$ & $3(14)$ \\
\hline
\end{tabular}

Table 1 Clinical features of the patients (continued)

\begin{tabular}{lll}
\hline & Present series & Literature \\
\hline Neurologic outcomes & & \\
\hline No. (\%) with available follow-up & $10(91)$ & $13(68)$ \\
\hline Median follow-up, mo (range) & $28(6-144)$ & $9(6-18)$ \\
\hline $\begin{array}{l}\text { Median mRS score at last } \\
\text { follow-up (range) }\end{array}$ & $1(0-4)$ & $1(0-3)$ \\
\hline
\end{tabular}

Abbreviations: ICU = intensive care unit; IVIg = IV immunoglobulin; mRS = modified Rankin Scale; NMDAR = NMDA receptor.

normal in 6/6 (100\%) (not provided for the other 5 newborns). One newborn, whose mother had developed NMDAR encephalitis at 20 weeks of gestation, presented with respiratory distress immediately after delivery (APGAR score not provided). This was considered an adverse effect of the antiepileptic and sedative drugs that had been administered to the mother, and the baby recovered spontaneously in less than 24 hours. Among 9 (81\%) infants with follow-up (median 18 months; range, 7-96 months), no developmental abnormality, atypical behavior, or abnormal interaction was reported. Only 1 newborn was tested for serum NMDAR antibodies and was found positive; he was reported healthy at birth and at the last follow-up (18 months) showed normal development and behavior.

\section{Review of previously reported patients}

A review of the English literature identified 19 publications reporting 21 cases of anti-NMDAR encephalitis during pregnancy (table 1). ${ }^{2-8,13-24}$ Median maternal age was 25 years (range, 18-36 years), and 18 (85.7\%) patients required intensive care. A teratoma was found and removed in 10/21 (47.6\%) patients. Two patients (10\%) died of septic shock during intensive care, one of them after the delivery of a baby (case with cortical dysplasia). Follow-up was provided for 13/ 19 (68.4\%) survivors, and $12(92.3 \%)$ of them had good neurologic outcomes (final mRS score $\leq 2$ ). Obstetrical complications were reported in 7/19 (36.8\%) patients (table 2). Two patients had miscarriages during the first trimester, and in another 2 patients, the pregnancy was terminated. ${ }^{2,17-19}$

\section{Review of outcomes of previously reported children}

In total, 16 children were born, 9 (56\%) preterm. A cesarean section was performed in 8 (50\%) mothers, either because their clinical status was deteriorating $(n=5)$ or there was fetal distress $(\mathrm{n}=3)$. Thirteen of $16(81.3 \%)$ newborns were considered healthy. The APGAR score at 5 minutes was normal in 5/9 infants (56\%; not provided for the other 7). One infant (mother's encephalitis at 7 weeks of gestation) had transient movement disorders after birth (5-minute APGAR score: 7/10) and during follow-up showed developmental delay and epilepsy due to cortical dysplasia. ${ }^{13}$ Another infant (mother's encephalitis at 37 weeks of gestation) was born 
Table 2 Obstetrical outcomes in pregnancies concomitant with NMDA receptor encephalitis

\begin{tabular}{lll}
\hline & Present series & Literature \\
\hline No. cases & 6 & 21 \\
\hline Median age, range & $23(19-37)$ & $24.5(18-36)$ \\
\hline Disease onset & & \\
\hline First trimester, $\mathbf{n}(\%)$ & $3(50)$ & $11(52)$ \\
\hline Second trimester, $\mathbf{n}(\%)$ & $2(33)$ & $7(33)$ \\
\hline Third trimester, $\mathbf{n}(\%)$ & $1(17)$ & $3(14)$ \\
\hline Complications & & $2(10)$ \\
\hline Death from septic shock, $\mathbf{n}(\%)$ & $0(0)$ & $7(33)$ \\
\hline Obstetrical complications, $\mathbf{n}(\%)$ & $0(0)$ & $2(10)$ \\
\hline Spontaneous miscarriage & $0(0)$ & $1(5)$ \\
\hline Uteroplacental insufficiency & $0(0)$ & $1(5)$ \\
\hline Eclampsia & $0(0)$ & $1(5)$ \\
\hline Hemorrhagic shock from & $0(0)$ & $2(10)$ \\
\hline vaginal bleeding & $0(0)$ & \\
\hline Unexplained fetal distress & & \\
\hline
\end{tabular}

\section{Delivery}

\begin{tabular}{|c|c|c|}
\hline No. (\%) children born & $6(100)$ & $16(76)$ \\
\hline Spontaneous miscarriage, $\mathrm{n}(\%)$ & $0(0)$ & $2(10)$ \\
\hline $\begin{array}{l}\text { Death of the mother before } \\
\text { delivery, } n(\%)\end{array}$ & $0(0)$ & $1(5)$ \\
\hline $\begin{array}{l}\text { Medical termination of } \\
\text { pregnancy, } n(\%)\end{array}$ & $0(0)$ & $2(10)$ \\
\hline Cesarean section, n (\%) & $4(67)$ & $8(50)$ \\
\hline Maternal indication ${ }^{a}$ & $4(100)$ & $5(63)$ \\
\hline Fetal indication ${ }^{\mathbf{b}}$ & $0(0)$ & $3(37)$ \\
\hline
\end{tabular}

a Treatment or procedures used to treat the mother may affect the fetus.

${ }^{b}$ The clinical status of the mother (e.g., severe autonomic dysfunction and uncontrolled seizures) is harmful to the fetus.

with hypotonia, hypoventilation, and seizure-like abnormal movements (5-minute APGAR score: $2 / 10){ }^{3}$ Brain MRI showed diffuse brain edema attributed to maternal antibodymediated encephalitis, and he died 3 weeks after birth. Another infant (mother's encephalitis at 20 weeks of gestation) had transient neuromuscular symptoms and respiratory depression (APGAR score: 4/10) likely related to sedative drugs administered to the mother. ${ }^{8}$ Follow-up was available in 10 children (63\%; median, 12 months; range, 6-36 months). All of them had normal development and behavior, except for the child with cortical dysplasia. Serum anti-NMDAR antibodies were tested in 6 newborns and found positive in 3, all with complications at birth (1 lethal encephalopathy; 1 cortical dysplasia with epilepsy and developmental delay, and 1 transient neuromuscular and respiratory deficit).

\section{Immunotherapy during pregnancy}

Immunotherapy was used in 7 (64\%) patients studied by us and in $18(86 \%)$ of the previously reported patients (table 1 ). No adverse effect was reported in any of the patients or infants. Twenty-one patients received IV steroids, $15 \mathrm{IV}$ immunoglobulin (IVIg), and 10 plasma exchange. In addition, rituximab was administered to 4 patients ( 1 from our cohort and 3 from the literature). Rituximab was started during the first trimester (2 patients) or the second trimester (2 patients), at a median of 21 weeks (range, 19-33 weeks) before delivery. In all 4 patients, rituximab was well tolerated and associated with clinical improvement. One of these patients also received IV cyclophosphamide 6 weeks before delivery. In all 4 cases, the babies were healthy without malformations, hypogammaglobulinemia, or leukopenia. None of the patients studied by us or previously reported who had a low 5-minute APGAR score, or any symptoms at birth, were exposed to rituximab or cyclophosphamide during pregnancy.

\section{Discussion}

In this study, we aimed to assess the effects of anti-NMDAR encephalitis on pregnancy, focusing on the obstetrical complications and outcome of mothers and babies. Because it has been suggested that transplacental transfer of maternal NMDAR antibodies may be harmful to the fetus, we focused on 2 settings associated with maternal levels of serum NMDAR antibodies: (1) pregnant women who developed anti-NMDAR encephalitis and (2) women who became pregnant while they were recovering from anti-NMDAR encephalitis. ${ }^{25}$ Placental transfer of maternal antibodies is critical for fetal protection against infections and begins at 12-13 weeks of pregnancy. ${ }^{26-28}$ However, at approximately the same time the blood-brain barrier of the fetus develops the ability to prevent the passage of endogenous albumin (and likely immunoglobulins) to the brain. Therefore, the amount of maternal antibodies that can actually reach the developing brain is unclear. ${ }^{29-31}$

Despite in utero exposure to NMDAR antibodies (in some cases from the first trimester onward), up to $90 \%$ of infants studied by us were healthy at birth, and all of those who had assessable follow-up (7-96 months) had normal development. Premature birth was common due to the frequent indication of cesarean section, although without obvious adverse effects on the babies. Moreover, review of the literature shows that only 3 of 16 infants whose mothers had antiNMDAR encephalitis during pregnancy developed neonatal encephalopathy. ${ }^{3,8,9}$ In 1 study, based in a single patient, the authors suggested that neonatal encephalopathy due to passive transfer of maternal NMDAR antibodies can potentially occur several years after the mother has recovered from the encephalitis as long as she remains anti-NMDAR seropositive. ${ }^{9}$ Other authors proposed that the absence of serum NMDAR antibodies in the mother (e.g., only detected in CSF) decreases the risk of problems in the newborn. ${ }^{5}$ 
Table 3 Children outcomes

\begin{tabular}{|c|c|c|}
\hline & Present series & Literature \\
\hline No. children & 11 & 16 \\
\hline \multicolumn{3}{|l|}{ Term of delivery } \\
\hline Full term, n (\%) & $4(36)$ & $3(19)$ \\
\hline Early term, n (\%) & $1(9)$ & $4(25)$ \\
\hline Preterm, n (\%) & $5(45)$ & $9(56)$ \\
\hline Extreme preterm, n (\%) & $1(9)$ & 0 \\
\hline \multicolumn{3}{|l|}{ Health status at birth } \\
\hline Healthy, n (\%) & $10(91)$ & $13(81)$ \\
\hline $\begin{array}{l}\text { Neuromuscular/respiratory } \\
\text { depression, } \mathrm{n}(\%)\end{array}$ & $1(9)$ & $1(6)$ \\
\hline $\begin{array}{l}\text { Transient abnormal } \\
\text { movements, } \mathrm{n}(\%)\end{array}$ & $0(0)$ & $1(6)$ \\
\hline $\begin{array}{l}\text { Severe encephalopathy and } \\
\text { death, } n(\%)\end{array}$ & $0(0)$ & $1(6)$ \\
\hline \multicolumn{3}{|l|}{$\begin{array}{l}\text { APGAR score } 5 \text { min } \\
\text { following delivery }\end{array}$} \\
\hline No. (\%) with data & $6(54)$ & $9(56)$ \\
\hline 7-10, n (\%) & $6(100)$ & $5(56)$ \\
\hline $4-6, n(\%)$ & $0(0)$ & $3(33)$ \\
\hline $0-3, n(\%)$ & $0(0)$ & $1(11)$ \\
\hline \multicolumn{3}{|l|}{ Outcome at last visit } \\
\hline No. (\%) with available follow-up & $9(81)$ & $10(63)$ \\
\hline Median follow-up, mo (range) & $18(7-96)$ & $12(6-36)$ \\
\hline $\begin{array}{l}\text { Healthy child with normal } \\
\text { development, } n(\%)\end{array}$ & $9(100)$ & $7(88)$ \\
\hline $\begin{array}{l}\text { Cortical dysplasia, epilepsy, and } \\
\text { mental retardation, } \mathrm{n}(\%)\end{array}$ & $0(0)$ & $1(12)$ \\
\hline
\end{tabular}

Although all 3 reported infants with detectable NMDAR antibodies at birth had neurologic symptoms, in our series, the only newborn that tested positive was healthy. It is likely that the neurologic symptoms described in those infants resulted from a combination of factors that may include the potential pathogenic effects of the antibodies (usually transient) along with the side effects of sedatives, antiepileptics, and other drugs used during the pregnancy. Except for 1 previously reported baby with cortical dysplasia (along with delayed global development and seizures) who was the product of a pregnancy with multiple complications, uteroplacental insufficiency, and delivery at gestational age 34 weeks, we have not identified other infants with neurodevelopmental disorders. ${ }^{13}$

In addition to the infants' outcomes, we reviewed the importance of obstetrical complications in patients who develop anti-NMDAR encephalitis during pregnancy. Although in our series we did not identify obstetrical complications, about one third of reported patients had pathologic pregnancy or spontaneous miscarriage that are likely related to the severe neurologic and medical problems of patients with this disease, often requiring intensive care admissions. Because pregnant patients with other diseases that may require prolonged intensive care are relatively infrequent in obstetrical cohorts, the comparison with those with anti-NMDAR encephalitis is difficult, and we have not been able to determine whether this disease causes more obstetric complications than other diseases that associate with similar degree of neurologic and systemic symptoms. ${ }^{32,33}$ Therefore, although the exact cause of these complications and their relation with anti-NMDAR encephalitis are unclear, autonomic dysfunction or seizures could have played a role. In late stages of pregnancy, uteroplacental blood flow comprises a large part of the maternal cardiac output, making the fetus particularly sensitive to variations of maternal blood pressure. ${ }^{34}$ For example, 3 patients underwent emergency cesarean sections due to signs of fetal distress, resulting in good outcome in 2 of them.

In most pregnant patients, the immunotherapies used are those described as first-line treatments (steroids, IVIg, and plasma exchange). Our experience and that reported in the literature indicate that these treatments are usually well tolerated. The experience with rituximab (which is often considered a second-line treatment) is limited to a few patients, and it was well tolerated. Previous retrospective studies and literature reviews on pregnant patients with autoimmune demyelinating diseases treated with rituximab did not show adverse effects on patients or newborns. ${ }^{35,36}$ Low B-cell counts may be observed in the infants, but they usually normalize spontaneously in the first 6 months without increased infection rates.

This study has limitations posed by its retrospective nature and the small number of cases available. The short follow-up of the infants (median 18 months in our series and 12 months in the literature) and the lack of systematic neuropsychological assessment may have potentially missed neurologic complications. On the other hand, the current frequency of complications identified in the literature, despite being small, probably represents a reporting bias whereby cases with complications are more likely to be reported. Over the years, we have learned of additional cases (not included in this report, and unable to track) of pregnant patients with anti-NMDAR encephalitis who delivered healthy babies.

Despite these limitations, the current findings are important to report in light of a recent study by Jurek et al., ${ }^{11}$ suggesting that in asymptomatic pregnant women (without evidence of previous history of anti-NMDAR encephalitis), transplacental transfer of serum NMDAR antibodies results in neuropsychiatric symptoms in the offspring. This study is very disconcerting for patients and families of patients with anti-NMDAR encephalitis because during the disease, these patients have high levels of NMDAR antibodies that usually remain detectable (albeit at low titer) for many months or years after recovery. However, the conclusions 
of Jurek et al. ${ }^{11}$ are based in a model of passive transfer of high amounts $(0.48 \mathrm{mg})$ of a monoclonal antibody derived from a patient with classic anti-NMDAR encephalitis to pregnant mice that resulted in $27 \%$ neonatal mortality and multiple symptoms during the postnatal and adult stages of the mice. This monoclonal antibody does not reflect the antibody repertoire of patients with anti-NMDAR encephalitis and, even less so, the antibodies of asymptomatic mothers of children with neurocognitive deficits. Moreover, there is no evidence that the antibodies of asymptomatic pregnant women (without a previous history of anti-NMDAR encephalitis) are the same as those antibodies occurring in anti-NMDAR encephalitis or have similar pathogenicity.

Overall, the current findings and previously reported cases suggest that in pregnant patients with anti-NMDAR encephalitis, fetal exposure to maternal NMDAR antibodies infrequently associates with overt neurologic deficits. Acute neonatal encephalopathy or neurodevelopmental disorders appear to be infrequent, and in such cases, other factors, not necessarily antibody related (e.g., drugs used during pregnancy, seizures or autonomic dysfunction of the mother, uteroplacental insufficiency, and premature delivery), may play a role. Obstetrical complications pose a serious threat to pregnant patients with NMDAR encephalitis, suggesting that these patients need to be monitored closely in intensive care units dedicated to high-risk pregnancies and treated early with first-line immunotherapy (e.g., steroids and IVIg). Considering our findings and those of larger series of patients with other CNS autoimmune disorders, rituximab is a potential treatment option in severely ill pregnant who fail first-line therapies. ${ }^{35}$ Our results suggest that pregnancy is not contraindicated in women with a history of antiNMDAR encephalitis. An important question to clarify is whether serum antibody titers in the mother and newborn correlate with the likelihood of neurologic deficits and developmental abnormalities. Future multi-institutional investigations on patients who develop anti-NMDAR encephalitis during pregnancy, or become pregnant after the acute phase of the disease, are needed. These studies should include neuropsychological assessments of the children with sufficient follow-up (24-36 months) to detect any delay in skill acquisition.

\section{Study funding}

This study was supported in part by Instituto Carlos III/ FEDER (JR17/00012, E.M.-H.; FIS 17/00234 and PIE 16/ 00014, J.D.); CIBERER (15/00010, J.D.); AGAURGeneralitat de Catalunya (2019FI B1 00212, A.G.-S.); Pla Estratègic de Recerca i Innovació en Salut (PERIS SLT002/ 16/00346, J.P.); La Caixa Foundation Health Research (J.D.); and Fundació CELLEX (J.D.).

\section{Disclosure}

B. Joubert, A. García-Serra, J. Planagumà, E. MartínezHernandez, and A. Kraft report no disclosures. T. Iizuka received a grant from The Japan Epilepsy Research Foundation and financial support from Astellas Pharma Inc. J. Honnorat reports no disclosure. F. Leypoldt reports having received speakers honoraria from Roche, Novartis, Bayer, Fresenius, and Grifols, serving as an advisory board member to Roche and Biogen, and working for an academic institute offering commercial autoantibody testing to third parties. F. Graus receives royalties from Euroimmun for the use of IgLON5 as an autoantibody test. J. Dalmau receives royalties from Athena Diagnostics for the use of Ma2 as an autoantibody test and from Euroimmun for the use of NMDA, GABAB receptor, GABAA receptor, DPPX and IgLON5 as autoantibody tests. He is editor of Neurology ${ }^{\circledR}$ Neuroimmunology \& Neuroinflammation. Go to Neurology.org/ $\mathrm{NN}$ for full disclosures.

\section{Publication history}

Received by Neurology: Neuroimmunology \& Neuroinflammation November 19, 2019. Accepted in final form December 19, 2019.

Appendix Authors

\begin{tabular}{|c|c|c|c|}
\hline Name & Location & Role & Contribution \\
\hline $\begin{array}{l}\text { Bastien } \\
\text { Joubert, MD }\end{array}$ & $\begin{array}{l}\text { University of } \\
\text { Barcelona }\end{array}$ & Author & $\begin{array}{l}\text { Designed and } \\
\text { conceptualized the } \\
\text { study; analyzed the data; } \\
\text { and drafted the } \\
\text { manuscript for } \\
\text { intellectual } \\
\text { content }\end{array}$ \\
\hline
\end{tabular}

\begin{tabular}{|c|c|c|c|}
\hline $\begin{array}{l}\text { Anna García- } \\
\text { Serra, MSc }\end{array}$ & $\begin{array}{l}\text { University of } \\
\text { Barcelona }\end{array}$ & Author & $\begin{array}{l}\text { Revised the manuscript } \\
\text { for intellectual content }\end{array}$ \\
\hline $\begin{array}{l}\text { Jesús } \\
\text { Planagumà, } \\
\text { PhD }\end{array}$ & $\begin{array}{l}\text { University of } \\
\text { Barcelona }\end{array}$ & Author & $\begin{array}{l}\text { Revised the manuscript } \\
\text { for intellectual content }\end{array}$ \\
\hline $\begin{array}{l}\text { Eugenia } \\
\text { Martínez- } \\
\text { Hernandez, } \\
\text { MD, PhD }\end{array}$ & $\begin{array}{l}\text { University of } \\
\text { Barcelona }\end{array}$ & Author & $\begin{array}{l}\text { Revised the manuscript } \\
\text { for intellectual content }\end{array}$ \\
\hline $\begin{array}{l}\text { Andrea } \\
\text { Kraft, MD }\end{array}$ & $\begin{array}{l}\text { Martha-Maria } \\
\text { Hospital, Halle }\end{array}$ & Author & $\begin{array}{l}\text { Major role in the } \\
\text { acquisition of data }\end{array}$ \\
\hline $\begin{array}{l}\text { Takahiro } \\
\text { lizuka, MD, } \\
\text { PhD }\end{array}$ & $\begin{array}{l}\text { Kitasato } \\
\text { University School } \\
\text { of Medicine, } \\
\text { Sagamihara }\end{array}$ & Author & $\begin{array}{l}\text { Major role in the } \\
\text { acquisition of data }\end{array}$ \\
\hline $\begin{array}{l}\text { Jérôme } \\
\text { Honnorat, } \\
\text { MD, PhD }\end{array}$ & $\begin{array}{l}\text { Hospices Civils de } \\
\text { Lyon }\end{array}$ & Author & $\begin{array}{l}\text { Major role in the } \\
\text { acquisition of data }\end{array}$ \\
\hline $\begin{array}{l}\text { Frank } \\
\text { Leypoldt, } \\
\text { MD, PhD }\end{array}$ & $\begin{array}{l}\text { Christian- } \\
\text { Albrechts- } \\
\text { University, Kiel }\end{array}$ & Author & $\begin{array}{l}\text { Major role in the } \\
\text { acquisition of data }\end{array}$ \\
\hline $\begin{array}{l}\text { Francesc } \\
\text { Graus, MD, } \\
\text { PhD }\end{array}$ & $\begin{array}{l}\text { University of } \\
\text { Barcelona }\end{array}$ & Author & $\begin{array}{l}\text { Revised the manuscript } \\
\text { for intellectual content }\end{array}$ \\
\hline $\begin{array}{l}\text { Josep } \\
\text { Dalmau, MD, } \\
\text { PhD }\end{array}$ & $\begin{array}{l}\text { University of } \\
\text { Barcelona }\end{array}$ & Author & $\begin{array}{l}\text { Designed and } \\
\text { conceptualized the } \\
\text { study; analyzed the data; } \\
\text { and drafted the } \\
\text { manuscript for } \\
\text { intellectual } \\
\text { content }\end{array}$ \\
\hline
\end{tabular}




\section{References}

1. Dalmau J, Lancaster E, Martinez-Hernandez E, Rosenfeld MR, Balice-Gordon R. Clinical experience and laboratory investigations in patients with anti-NMDAR encephalitis. Lancet Neurol 2011;10:63-74.

2. Kumar MA, Jain A, Dechant VE, et al. Anti-N-methyl-D-aspartate receptor encephalitis during pregnancy. Arch Neurol 2010;67:884-887.

3. Chourasia N, Watkins MW, Lankford JE, Kass JS, Kamdar A. An infant born to a mother with anti-N-methyl-d-aspartate receptor encephalitis. Pediatr Neurol 2018;79:65-68.

4. Liao Z, Jiang X, Ni J. Anesthesia management of cesarean section in parturient with anti-N-methyl-D-aspartate receptor encephalitis: a case report. J Anesth 2017;31: 282-285.

5. Ueda A, Nagao R, Maeda T, et al. Absence of serum anti-NMDAR antibodies in antiNMDAR encephalitis mother predicts having healthy newborn. Clin Neurol Neurosurg 2017;161:14-16.

6. Xiao X, Gui S, Bai P, et al. Anti-NMDA-receptor encephalitis during pregnancy: a case report and literature review. J Obstet Gynaecol Res 2017;43:768-774.

7. McCarthy A, Dineen J, McKenna P, et al. Anti-NMDA receptor encephalitis with associated catatonia during pregnancy. J Neurol 2012;259:2632-2635.

8. Lamale-Smith LM, Moore GS, Guntupalli SR, Scott JB. Maternal-fetal transfer of antiN-methyl-D-aspartate receptor antibodies. Obstet Gynecol 2015;125:1056-1058.

9. Hilderink M, Titulaer MJ, Schreurs MWJ, Keizer K, Bunt JEH. Transient antiNMDAR encephalitis in a newborn infant due to transplacental transmission. Neurol Neuroimmunol Neuroinflamm 2015;2:e126. doi: 10.1212/NXI.0000000000000126.

10. Coutinho E, Jacobson L, Pedersen MG, et al. CASPR2 autoantibodies are raised during pregnancy in mothers of children with mental retardation and disorders of psychological development but not autism. J Neurol Neurosurg Psychiatry 2017;88:718-721.

11. Jurek B, Chayka M, Kreye J, et al. Human gestational NMDAR autoantibodies impair neonatal murine brain function. Ann Neurol 2019;86:656-670.

12. Banks JL, Marotta CA. Outcomes validity and reliability of the modified Rankin scale: implications for stroke clinical trials: a literature review and synthesis. Stroke 2007;38: 1091-1096.

13. Jagota P, Vincent A, Bhidayasiri R. Transplacental transfer of NMDA receptor antibodies in an infant with cortical dysplasia. Neurology 2014;82:1662-1663.

14. Shahani L. Steroid unresponsive anti-NMDA receptor encephalitis during pregnancy successfully treated with plasmapheresis. BMJ Case Rep 2015;2015:bcr2014208052.

15. Mathis S, Pin JC, Pierre F, et al. Anti-NMDA receptor encephalitis during pregnancy: a case report. Medicine (Baltimore) 2015;94:e1034.

16. Lu J, Samson S, Kass J, Ram N. Acute psychosis in a pregnant patient with Graves' hyperthyroidism and anti-NMDA receptor encephalitis. BMJ Case Rep 2015;2015: bcr2014208823.

17. Kim J, Park SH, Jung YR, Park SW, Jung DS. Anti-NMDA receptor encephalitis in a pregnant woman. J Epilepsy Res 2015;5:29-32.

18. Chan LW, Nilsson C, Schepel J, Lynch C. A rare case of anti-N-methyl-D-aspartate receptor encephalitis during pregnancy. N Z Med J 2015;128:89-91.

19. Kokubun N, Komagamine T, Hirata K. Pregnancy and delivery in anti-NMDA receptor encephalitis survivors. Neurol Clin Pract 2016;6:e40-e43.
20. Kalam S, Baheerathan A, McNamara C, Singh-Curry V. Anti-NMDAR encephalitis complicating pregnancy. Pract Neurol 2019;19:131-135.

21. Grewal KS, Bhatia R, Singh N, Singh R, Dash D, Tripathi M. Confusional state in a pregnant woman: a case of NMDA receptor encephalitis during pregnancy. J Neuroimmunol 2018;325:29-31.

22. Keskin AO, Tanburoglu A, Idiman E, Ozturk V. Anti-N-methyl-d-aspartate receptor encephalitis during pregnancy: a case report. J Obstet Gynaecol Res 2019;45: 935-937.

23. Mizutamari E, Matsuo Y, Namimoto T, Ohba T, Yamashita Y, Katabuchi H. Successful outcome following detection and removal of a very small ovarian teratoma associated with anti-NMDA receptor encephalitis during pregnancy. Clin Case Rep 2016;4:223-225.

24. Demma L, Norris S, Dolak J. Neuraxial anesthesia in a patient with anti-N-methyl-Daspartate receptor encephalitis in pregnancy: management for cesarean delivery and oophorectomy. Int J Obstet Anesth 2017;31:104-107.

25. Gresa-Arribas N, Titulaer MJ, Torrents A, et al. Diagnosis and significance of antibody titers in anti-NMDA receptor encephalitis, a retrospective study. Lancet Neurol 2014; 13:167-177.

26. Simister NE. Placental transport of immunoglobulin G. Vaccine 2003;21:3365-3369.

27. Dancis J, Lind J, Oratz M, Smolens J, Vara P. Placental transfer of proteins in human gestation. Am J Obstet Gynecol 1961;82:167-171.

28. Malek A, Sager R, Kuhn P, Nicolaides KH, Schneider H. Evolution of maternofetal transport of immunoglobulins during human pregnancy. Am J Reprod Immunol 1996;36:248-255.

29. Virgintino D, Robertson D, Benagiano V, et al. Immunogold cytochemistry of the blood-brain barrier glucose transporter GLUT1 and endogenous albumin in the developing human brain11Published on the World Wide Web on 24 August 2000. Dev Brain Res 2000;123:95-101.

30. Virgintino D, Errede M, Robertson D, et al. Immunolocalization of tight junction proteins in the adult and developing human brain. Histochem Cell Biol 2004;122: $51-59$.

31. Saunders NR, Dziegielewska KM, Møllgård K, Habgood MD. Physiology and molecular biology of barrier mechanisms in the fetal and neonatal brain. J Physiol (Lond) 2018;596:5723-5756.

32. Seppänen PM, Sund RT, Uotila JT, Helminen MT, Suominen TM. Maternal and neonatal characteristics in obstetric intensive care unit admissions. Int J Obstet Anesth 2019. doi:10.1016/j.ijoa.2019.07.002.

33. Chantry AA, Deneux-Tharaux C, Bonnet M-P, Bouvier-Colle M-H. Pregnancyrelated ICU admissions in France: trends in rate and severity, 2006-2009. Crit Care Med 2015;43:78-86.

34. Crozier TME. General care of the pregnant patient in the intensive care unit. Semin Respir Crit Care Med 2017;38:208-217.

35. Das G, Damotte V, Gelfand JM, et al. Rituximab before and during pregnancy. Neurol Neuroimmunol Neuroinflamm 2018;5:e453. doi: 10.1212/NXI.0000000000000453.

36. Chakravarty EF, Murray ER, Kelman A, Farmer P. Pregnancy outcomes after maternal exposure to rituximab. Blood 2011;117:1499-1506. 


\section{Neurology \\ Neuroimmunology \& Neuroinflammation}

Pregnancy outcomes in anti-NMDA receptor encephalitis: Case series

Bastien Joubert, Anna García-Serra, Jesús Planagumà, et al.

Neurol Neuroimmunol Neuroinflamm 2020;7;

DOI 10.1212/NXI.0000000000000668

This information is current as of January 16, 2020

\section{Updated Information \& Services}

References

Citations

Subspecialty Collections

Permissions \& Licensing

Reprints including high resolution figures, can be found at: http://nn.neurology.org/content/7/3/e668.full.html

This article cites 35 articles, 9 of which you can access for free at: http://nn.neurology.org/content/7/3/e668.full.html\#\#ref-list-1

This article has been cited by 6 HighWire-hosted articles: http://nn.neurology.org/content/7/3/e668.full.html\#\#otherarticles

This article, along with others on similar topics, appears in the following collection(s):

Autoimmune diseases

http://nn.neurology.org//cgi/collection/autoimmune_diseases

Developmental disorders

http://nn.neurology.org//cgi/collection/developmental_disorders

Neonatal

http://nn.neurology.org//cgi/collection/neonatal

Information about reproducing this article in parts (figures,tables) or in its entirety can be found online at:

http://nn.neurology.org/misc/about.xhtml\#permissions

Information about ordering reprints can be found online: http://nn.neurology.org/misc/addir.xhtml\#reprintsus

Neurol Neuroimmunol Neuroinflamm is an official journal of the American Academy of Neurology.

Published since April 2014, it is an open-access, online-only, continuous publication journal. Copyright Copyright $\odot 2020$ The Author(s). Published by Wolters Kluwer Health, Inc. on behalf of the American Academy of Neurology.. All rights reserved. Online ISSN: 2332-7812.

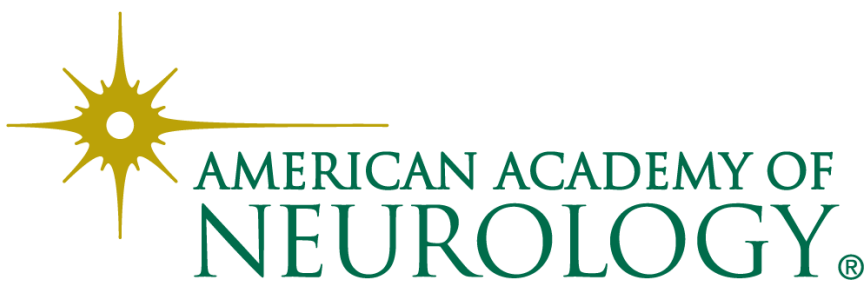

